Portland State University

PDXScholar

1973

\title{
A study of a token economy program initiated at Oregon State Hospital
}

Helenjane R. Kudelko

Portland State University

Follow this and additional works at: https://pdxscholar.library.pdx.edu/open_access_etds

Part of the Mental Disorders Commons, Psychiatric and Mental Health Commons, and the Social Work Commons

Let us know how access to this document benefits you.

\section{Recommended Citation}

Kudelko, Helenjane R., "A study of a token economy program initiated at Oregon State Hospital" (1973). Dissertations and Theses. Paper 1716.

https://doi.org/10.15760/etd.1715

This Thesis is brought to you for free and open access. It has been accepted for inclusion in Dissertations and Theses by an authorized administrator of PDXScholar. Please contact us if we can make this document more accessible: pdxscholar@pdx.edu. 


\section{A STUDY OF A TOKEN ECONOMY PROGRAM INITIATED AT OREGON \\ STATE HOSPITAL}

by

Helenjane R. Kudelko

A study submitted in partial fulfillment

of the requirements for the degree of

MASTER OF SOCIAL WORK

Portland State University

1973

APPROVED:

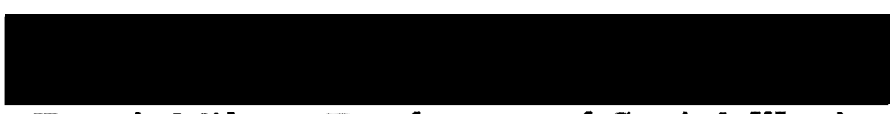

Frank Miles, Professor of Social Work 


\section{ACKNOWLEDGMENTS}

I wish to express appreciation to the following people for their assistance in the preparation of this study.

First and foremost, I would like to thank Dr. D. K. Brooks, Superintendent of Oregon State Hospital, for his permission to do this study. I would also like to thank Adele McHale, Librarian, Medical Records, Oregon State Hospital, for her invaluable aid. Gratefulness is extended to Dr. John Reid, Oregon Research Institute, and to Dr. John Taylor, Marion County Mental Health Department, for the loan of valuable material pertinent to this study.

To Jo-Ann and Richard Reece I extend thanks for their assistance in tabulating early test results. A particular thank you is extended to Paul M. Farrar, Psychology Department, University of Oregon, for his invaluable assistance in the statistical portion of this study.

A very special thank you to my advisor, Dr. Frank Miles, Professor of Social Work, for his tremendous patience and valuable constructive criticism.

I am particularly grateful to Mrs. Eleanor Koetz, former 
Director of Social Services at Oregon State Hospital, for her encouragement and support.

Above all, I wish to thank Dr. C. Dolores Gregory, psychiatrist in charge of the Token Economy Ward, not only for her permission to conduct this study, but for her unfailing support and encouragement.

And last, but certainly not least, a debt of gratitude is due to Hattie Lowrie, R. N. and to all of the aides who served as raters, making this study possible. 
TABLE OF CONTENTS

PAGE

ACKNOWLEDGMENT .................. . . . . ii

LIST OF TABLES ................... vi vi

\section{CHAPTER}

I. INTRODUCTION ............... 1

II. REVIEW OF THE LITERATURE . . . . . . 7

III. METHODOLOGY ............. 13

Study Design ............ 13

Description of the Agency ........ 16

Patient Selection............ 17

Process of Data Collection and Analysis... 20

Limitations Using Patients' Files..... . 21

Problems Encountered ......... 21

IV. FINDINGS ............... 39

V. EVALUATION ............... 49

VI. CONCLUSIONS ....................... 51

LIST OF FOOTNOTES ................. 54

A SELECTED BIBLIOGRAPHY . . . . . . . . . . . 57 


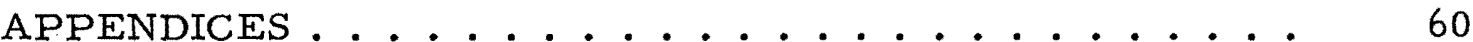

Appendix A: The MAAC Behavioral Adjustment Scale:

Revised 1971 (Ellsworth)......... 60

Appendix B: Token Economy Manual ......... 62 


\section{LIST OF TABLES}

TABLE

PAGE

I. Summary Statistics for MACC Raw

Scores of Six Testing Periods

Using Time-Series Design . . . . . .

II.

Agreement Between Raters Using

Pearson's $x$............

III. Observed Data for Test of Association

Between Sex and Improvement . . . . . .

IV. ANOVA Between Raters /Evaluation Dates . . $\quad 43$

V. ANOVA Between Patients .......... 


\section{CHAPTER I}

\section{INTRODUCTION}

The purpose of this study was to evaluate a token economy program at Oregon State Hospital in terms of patients' behavioral improvement during the first seventy days of the program. As the study progressed, it became apparent that a study of the problems involved in initiating this program would be significant. Thus an attempt has been made to evaluate both the patients' behavioral improvement and the problems involved in setting up an effective token economy program.

Prior to the June 1, 1972 reorganization of the hospital, the county geographical unit system had been in effect for approximately eleven years. On June 1st, three admission wards, two social remotivation wards, a behavior modification ward, two self-care wards and a token economy ward were established.

Although token economy programs have been widely used in state mental hospitals and in Veterans Administration Psychiatric hospitals across the country, this was the first attempt to use this type of operant conditioning therapy at Oregon State Hospital. 
A major problem at Oregon State Hospital, as well as in a number of other state mental hospitals, is the large group of patients who have become institutionalized. These patients have become apathetic and lack motivation to leave the hospital. Maintaining this pool of chronic patients in the hospital is not only costly to the taxpayer, $\$ 682.00$ a month for each patient for maintenance and treatment, but costly in terms of human waste. Unfortunately, as Ayllon and Azrin point out in their landmark study, in most mental hospitals the patients who receive most of the attention are not the chronic patients, but those 45 years of age or younger with some vocational skills and ties to the community. Thus the patients with the best prognosis for discharge are recipients of the most intensive therapy and study. The median age of state mental hospital patients, according to the Ayllon and Azrin study, is approximately 65 years. This group has long been abandoned by the community and any skills they may have once possessed have long been lost. ${ }^{*}$ Chronic patients in the V.A. Psychiatric hospitals tended to be younger, mid-forties, and predominantly male. But they too had spent many years in the hospital. 2 The use of various types of therapy, ranging from psychoanalysis to drug therapy failed to move the se chronic psychotic

* See footnotes beginning page 54 . 
patients out of the hospitals. Operant conditioning, as a method of treatment was seldom, if ever used. However, the Laws of Reinforcement and Extinction, basic to operant conditioning, had been accepted by major learning theorists since $1935 .^{3}$

Token economy therapy is based on Operant Reinforcement Theory. The dominant feature of this theory is that behavior is greatly influenced by the changes that the behavior produced in a particular environment. When a favorable consequence results from a behavior, it is called a positive reinforcement. The effect is an increase in this behavior. The Law of Reinforcement and the Law of Extinction provide concrete procedures for increasing the frequency of a desired behavior and decreasing an undesired behavior, respectively. Verbal and material rewards, such as candy and cigarettes, are extremely difficult to record and supervise with accuracy. To overcome this problem tokens have been substituted for these rewards. Token have the advantage of being easily recorded and supervised, and they can be exchanged at any point in time for verbal or material rewards. Thus token economy therapy is a method of reinforcing desirable behavior and extinguishing undesirable behavior.

Why was this major type of therapy neglected in mental hospitals? Brown attributes the disregard of this method, at least 
in part, to the emphasis on traditional methods by mental health professionals. Brown notes, lit is a sobering experience to reflect on the fact that now, after a half-century, the systematic applied use of principles of learning and conditioning in psychotherapeutic work both with children and adults is only now getting underway in substantial numbers of mental health centers, institutions, etc. $1{ }^{4}$ In the early part of 1961 Ayllon and Azrin, pioneers in the use of token economy therapy conceived of the token economy approach as a system of therapy for the mentally ill. They submitted their proposal to the Illinois Psychiatric Training and Research Fund on June 6, 1961. They subsequently initiated their token economy study in the Anna State Hospital in Illinois. They delayed publication of their first results, although they felt the program was successful, until 1965. They wished to rule out possible side effects that could negate their positive findings and they also wished to determine whether or not the positive effects of the program were transient. During the intervening years they modified and deleted portions of their program. 5

In 1964 the Veterans Administration introduced the first token economy program into a V. A. hospital. It was not until 1968 and 1969, however that token economy programs proliferated throughout the Veterans Administration system. In 1970 over 900 
patients in V. A. hospitals were involved in token economy programs. There were 17 token economy programs in $20 \mathrm{~V}$. A. hospitals. Numerous studies were conducted in connection with the se programs and the findings indicated that the programs were effective in returning chronic patients to the community. 6

The movement in state mental hospitals was not as rapid. Oregon State Hospital has a budget that allows $\$ 0.7962$ per patient per day for food; granted surplus foods augment this sum, one can readily see that funds for experimental programs might be difficult, if not impossible to obtain.

As drug therapy reduced the number of patients in the mental hospital, the plight of the long term institutionalized patient became more visible. The Smith study, reported in 1972 , supports the findings of Goffman and Vail that significant dehumanization does occur in state mental institutions. ${ }^{7}$ Goffman describes this as "the institutional desocialization syndrome" and Gruenberg has described it as "the social breakdown syndrome. 18

Institutionalization is generally thought of as a state of being due to long term confinement in a mental institution. However, Karmel found that the major movement toward chronicity occurs within the first two years of hospitalization. He found that the patients tend to lose "a home-world social identity while tending 
not to adopt a hospital world social identity to match the loss." He found that the patients tended to reject the staff world, viewing it as source of aggression. He noted also that interaction in the patient's world, because of conditions imposed on it, was not conducive to the necessary social processes that permit establishment of a deviant identity through the development of a sub-culture. 9

Also contributing to chronicity is the infrequent professional review of the chronic patient's clinical status in some mental hospitals. Other factors are the patient's broken ties in the community and his acceptance of the status, mental patient. 10

The traditional methods of treatment have not been effective with this group of patients. Perhaps a contributing factor in the slow spread of token economy therapy in state mental hospitals, is the criticism that in using operant conditioning the controller imposes his will on the subject. Control of human beings in our society is viewed by some with abhorrence. However, as Schaefer and Martin point out, the controller is not really independent of the controlled. If the experimenter does not take into account the idiosyncrasies, wishes, intentions and aversions of the person whose behavior he seeks to influence, he cannot succeed. The behavioral therapist's actions are controlled by the patient (subject) as much as the therapist controls the actions of the patient. 
This has been established by scientific experiments. ${ }^{\text {Il }}$ As there can be no legitimate objections to this method of therapy and as the studies have shown that it is effective with this "hard-core" group of patients, it deserves a place in the range of therapies available to the mental patient. 


\section{CHAPTER II}

\section{A REVIEW OF THE LITERATURE}

A survey of the literature reveals that during the past decade there has been a proliferation of books and journal articles dealing with token economy therapy. Populations studied have ranged from mental patients to delinquents. Brown did a content analysis of the two major journals dealing with the subject of behavior modification; The Journal of Behaviour Research and Therapy and The Journal of Applied Behavior Analysis. They were examined from 1963 and 1968 respectively to June 1969. Brown found that approximately 300 articles had been published relating to the application of behavior modification as a therapeutic procedure. 12

A review of token economy studies, beginning with Ayllon and Azrin's landmark study $(1965,1968)$ shows that token economy programs for the mentally ill, as well as for other populations expanded at a rapid rate after 1969. The studies and research, however have left important questions unanswered; e.g., what type of patients do or do not benefit from token economy therapy? Does generalization take place in a non-treatment setting? Kazdin and 
Bootzin in a 1972 evaluative review of token economy studies, point out that there have been "only a few systematic outcome studies."

Token economy studies for the mentally ill have also varied in their focus. Ayllon and Azrin $(1965,1968)$ were concerned with self-care behaviors and improved behavior on the ward. These behaviors were also the focus of studies by Atthowe and Krasner (1968); Ellsworth (1969); Golub (1969); Lloyd and Garlington (1968) and Steffy et al., (1969). ${ }^{13}$ Modification of social behavior and apathy were the target behaviors in studies by Henderson and Scoles (1970); Scoles and Henders on and Henderson (1969) and Schaefer and Martin (1966). The latter was one of the few studies that used a control group. Decreasing aggressive behavior was the main area of interest in the Steffy et al., study (1968). Curran, Jourd and Whitman (1968) used both positive and negative reinforcers in their study of behaviors relating to self control, work performance and self-care behaviors.

There have been few studies comparing the effectiveness of token economy programs with other types of therapy. Marks et al., (1968) did compare Relationship therapy with contingent token reinforcement. The target behaviors were work competence, communication skills and social behavior. They found both treatments equally effective. Hartlage (1970) compared contingent 
reinforcement with Individual therapy. He found the former most effective for chronic schizophrenic patients. ${ }^{14}$ There are a dearth of studies in this area, and certainly more research is needed to determine the most effective type of treatment for specific types of patients.

Most of the studies have emphasized over-all change on the ward rather than changes in the behavior of the individual patients. Ayllon and Azrin (1965, 1968); Atthowe and Krasner (1968); Curran et al., (1968); Lloyd and Abel (1970); and Schaefer and Martin (1966) have all focused on the change taking place on the ward rather than the change in the patient. ${ }^{15}$ There have also been few studies using objective behavior rating scales. One of the few, and it was limited to two dimensions of behavior, was the Steffy et al., (1969) study. 16

In regard to studies measuring change on an over-all ward basis rather than on an individual basis, Sidman (1960) defined the problem of using group statistics. Their use makes it impossible to fully evaluate the effectiveness of contingent reinforcement therapy. They mask the problem of the high responder, the patient who responds with or without reinforcement and the low responder who tends not to respond to reinforcement. A group figure does not indicate whether a few high responders changed 
or a large number of low responders.

Allen and Magaro found that the high responders in their study responded indiscriminately under free and reinforced conditions. The high responders were also found to be most sensitive to the "extra reward" possible in the token economy program. The contingency reinforcement stimulates behavioral responses already being emitted at a high frequency. The authors point out that this group appears to be functioning above the level of the token economy, as they do not require reinforcement to respond. This group, the authors state, are frequently found in token economy programs. Including the behavior of this group in statistics for the ward, distorts the findings of the number of patients who changed because of the introduction of the contingency reinforcement. Despite the se findings researchers continue to use group statistics. 17

Zeisel (1968) pointed out that "a percent figure merely describes a set of numbers and is not meant to suggest the underlying causes in the change. $1{ }^{18}$

Another serious gap in the literature is the lack of information regarding response generalization; are the effects of the program limited to the target behavior in the hospital setting or do they generalize to the outside community? Ayllon and Azrin (1968) 
tried to take generalization into effect with their "Relevance of Behavior Rule; Teach only those behaviors that will continue to be reinforced after training."

Kazdin and Bootzin point out that response generalization has received little empirical investigation in token reinforcement programs. 20

In summary, although there is a good deal of literature dealing with the various aspects of token economy therapy, there are urgent unanswered questions which must be answered by the researchers if token economies are to be effective. 


\section{CHAPTER III}

\section{METHODOLOGY}

This chapter describes the rating scale and research design used to evaluate the token economy program at Oregon State Hospital. The specific objective of the study was to determine whether or not changes had taken place in the individual patients during the first seventy days of the program. As the study progressed, it became apparent that there were a number of problems that affected not only the token economy program but this study. These problems as well as the study will be discussed.

It was apparent early in the study that there were factors beyond the control of this writer, which were adversely affecting the validity of the study. The decision was made, however, to continue with the original research design. The purpose in continuing was to examine and evaluate the surfacing problems in terms of future research.

\section{STUDY DESIGN}

The majority of studies have used the $A B A B$ research 
design with the subject serving as his own control. A baseline for each patient is obtained and the reinforcement is alternately presented and withdrawn. If the behavior of the patient improves whenever reinforcement is presented and declines whenever. treatment is withdrawn over a period of time, the conclusion can be drawn that the reinforcement program is effective. Although researchers have pointed out the limitations of this design, Kazdin and Bootzin state, "it still provides the most practical evaluative tool for evaluating ongoing programs. " They also note that the within-subject design (patient serves as his own control) is preferable in most cases due to practical problems within the hospital setting. 21

It was not feasible to use the A B A B design for this study, as it was beyond the scope of this writer to control the contingency reinforcements. It was necessary, therefore, to superimpose a research design on the existing structure. The decision was made to use the Time-Series design. There are a number of weaknesses in this design, including history. Campbell points out, however, that the design can be used if a careful log of non-experimental stimuli of possible relevance is kept, and if the design is used in a setting that could claim experimental isolation in the sense that the researcher could be aware of possible rival events that might 
cause change which could be attributed to the experimental stimuli. The researcher needs to be able to state that rival events did not occur in such a pattern as to provide an explanation for the results of the experiment. 22

The Time-Series study design used is outlined below:

$0_{1}$ pre-rating obtained from patients' old wards, May 29, 1972

X June 1, 1972 token economy program initiated

$0_{2}$ June 15,1972 rating

$0_{3}$. June 30,1972 rating

$0_{4} \quad$ July 15,1972 rating

$0_{5}$ July 30,1972 rating

$0_{6}$ August 10, 1972 final evaluation

The MACC Behavioral Adjustment Scale: Revised 1971

(Ellsworth) was used. This test was chosen because it was brief. It is composed of 16 questions dealing with patient's mood, cooperation, communication and social contact. Five possible ratings were possible for each question. The test was designed to quickly assess the behavioral adjustment of psychiatric patients. It evaluates the patients' adaptation to various ward and off-ward situations, regardless of psychopathology. It can be completed by any staff member on the ward who knows the patient. Ellsworth 
states that the scale discriminates well between patients identified by outside criteria as "well adjusted" and "poorly adjusted." It also correlates well with ratings by others using different scales. It is not, however, especially predictive of behavior adjustment in a different setting. The MACC Scale and other scales do generally have a high correlation when behavior is rated in a particular setting. It has been used successfully in major research studies evaluating difference in treatment effectiveness. 23

The scores of female patients and male patients were not significantly different when rated in the hospital or in the community, therefore separate norms for male and female patients are not used by Ellsworth.

Three raters are suggested to stabilize scores. After a small sample of patients have been rated, a comparison of raters is suggested. If one rater consistently rates a patient well adjusted when the others rate him poorly adjusted or if his ratings are consistently higher or lower than the others, Ellsworth suggests either working with that rater or using a different rater. ${ }^{24}$

\section{DESCRIPTION OF THE AGENCY}

The study took place at Oregon State Hospital located in Salem. The hospital was founded in 1883. There are approximately 72 
buildings on some 190 acres of land. Twenty-five of the buildings were constructed for residential use by staff members. Today a number of these structures are being used for other purposes. The buildings range from antiquated structures to stark, modern buildings. The token economy ward was located in one of the older buildings. The ward entrance was dreary and dark, however the ward did have the advantage of a large sunny day room, which could be closed off from the main hall. The high ceilings kept the ward reasonably cool during the summer. Each sleeping area (male and female) had only two private rooms, one of which was used for a seclusion room. The rest of the sleeping area was open, except for partial separations. The nurses'station (office) was located off of the center of the main hall. It was a small, inadequate room. There was insufficient space for staff or records. The structure of the office was such that patients in the main hall were not directly visible. It was necessary for patients to stand in the doorway, if they wished to gain the attention of the staff member at the desk. This became a problem, as will be discussed later.

\section{PATIENT SELECTION}

Patients were selected for the token economy program prior to June 1, 1972 by the Staff Psychiatrist, social worker and the nursing staff. The criterion for selection was the patient's projected 
ability to function in a job in the community outside of the hospital. A total of fifty-five patients, thirty-three males and twentytwo females were selected for assignment to the ward. On June lst forty-four patients, twenty-eight males and sixteen females, actually came to the ward. Five patients, three females and two males left the hospital on unauthorized leave June Ist. Three of the se patients never came to the ward, one was murdered while hitch-hiking and one returned to the ward after this study was completed. Six of the patients either requested transfers or were put on trial visit status. The forty-four patients who came to the ward represented twenty counties in Oregon. Their ages ranged from 15 to 66 with a mean of 33 years.

During the course of the study eighty-one patients entered the ward. Ratings were obtained for all of the se patients, however a decision was made to include only those patients that came to the ward on June 1, 1972 and remained until August 10, 1972. A total of twenty-nine patients were on the ward June Ist and remained there until the study was completed, August 10th. This cohort became the subject of this study. Patients not included in the final tabulation either left the ward before August 10th or arrived on the ward after June lst or both. 
The diagnoses of the 29 patients studied were as follows:

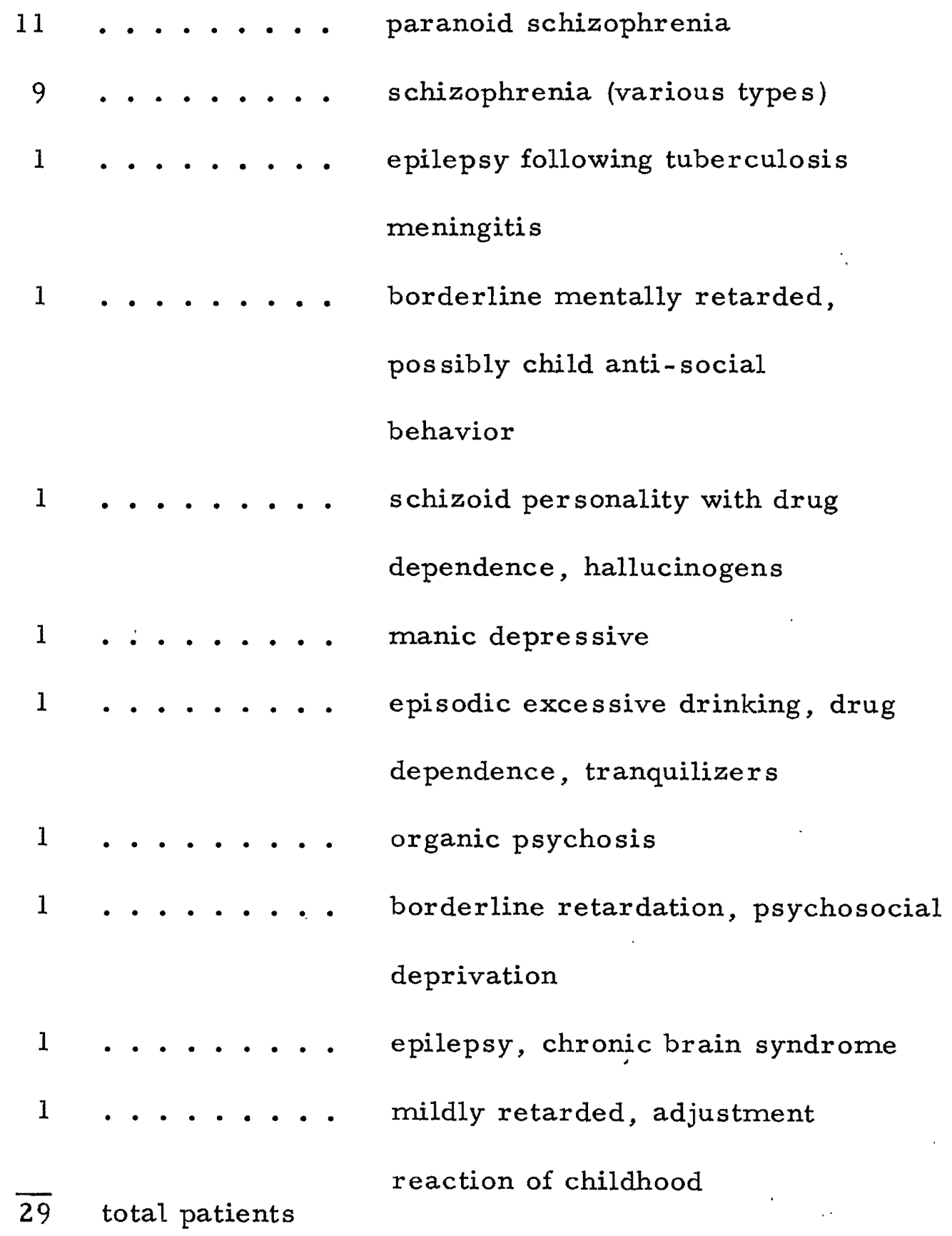




\section{PROCESS OF DATA COLLECTION AND ANALYSIS}

The original plan called for two raters on the day shift, two raters on the swing shift and one rater on the night shift. However, due to problems which will be discussed later, the decision was made to use only two raters, not necessarily the same raters, from either the day shift or swing shift.

A rating was obtained for each patient in regard to his behavior prior to his arrival on the token economy ward. A series of ratings were obtained beginning June 15 th and continuing every fifteen days until July 30th. A final evaluation of the patient was obtained on August 10th, the closing date of this study. A standard score and a raw score were obtained for each patient. A total of eighty-one patients were tested and scored, however a number of the se patients arrived on the ward after June lst and a number of them left before the study period was completed. An evaluation was made of the data and a decision was made to use only the patients who had entered the ward on June 1st and were still on the ward the closing day of the study. August 10th.

$\therefore$ A single rater was used for the final evaluation. The particular rater used was consistent and stable in her previous ratings, and knew all of the patients well. She had been employed 
by the hospital for $11 / 2$ years. Due to staff shortages, which will be discussed later in this paper, it was decided that one stable rater would give a more valid rating than two reluctant raters. Ratings were tabulated for each patient and statistical tests were done to determine whether or not the patient's behavior changed during the seventy day test period.

A study was also made of each patient's file to determine diagnosis, marital status, education, viable family ties, work history and length of hospitalization. It was originally planned to correlate this information with the test results.

\section{LIMITATIONS USING PATIENTS' FILES}

The original patient file kept in the Medical Records

Department, as well as the current file kept on the ward were examined. The files were inadequate for the purposes of this study. Information regarding the patient's social history was sparse and scattered throughout the file, thus a time consuming search had to be made of each patient file. After a careful perusal of each file, the plan to correlate the social factors noted above was abandoned.

\section{PROBLEMS ENCOUNTERED}

The first problem that arose delivered a crushing blow to the 
token economy program. A nur se experienced in setting up token economy programs was assigned to the ward. Although other staff members had some knowledge of token economy principles, they were not experienced in setting up token economy programs. This nurse did not arrive on the ward until the program was underway. Due to illness she resigned before this study was complete, after several lengthy absences from the ward. There was a good deal of pressure to put the program into operation. The hospital administration expected all wards, after the June 1, 1972 reorganization to begin functioning. The patients, accustomed to an open ward with free T. V., food, bed and recreation were becoming restless as they learned they would be on a closed ward and would have to now earn the se items.

Although a program was put into effect, some of the most important aspects of a token economy program were lacking. The staff, particularly the aides, did not receive training insofar as token economy principles were concerned. Weeks after the program was in effect aides expressed ignorance of the se principles and their behavior was counter to the se principles. Staff meetings were held weekly and the aides were included. During the se meetings patient and aide behavior was discussed, but the aides were not exposed to a training program of the type recommended 
by researchers. There were several reasons for this: The number of aides assigned to the ward was the same number other wards in the hospital received. They were expected to continue regular ward duty, therefore there was a lack of physical time for the necessary training. There was also a lack of financial support for the program. Although training films and training material is available, financial resources are necessary to instigate a training program. Aides would not, understandably, come to such training programs on their days off without compensation. Normal ward routines had to be blended with hasty lessons in operating a token economy ward.

Most of the aides had been with the hospital a number of years, thus it was extremely difficult for some of them to move from a custodial orientation to token economy orientation. A number of aides expressed the feeling, particularly during the early part of the program, that this was just another innovation which would pass as had the many other innovations they had witnessed during their years with the hospital. Some felt the entire reorganization was simply a return to the old back-ward system. To a number of aides the token economy program simply represented more work, particularly more paper work, which they did not welcome.

Another serious problem was inadequate staffing for a new 
program. Although two male aides and two female aides were assigned to the day shift and to the swing shift, and one male and one female aide to the night shift, in practice due to illness; vacations and a mountain climbing trip sponsored by the hospital June 30 th to August 15 th which included fifty-one staff members throughout the hospital, the ward was often shorthanded. One result of this was an emphasis on ward duties rather than on the patients. A baseline for each patient, which is a time-consuming process necessitating ample staff, was not obtained. A baseline is considered essential for a token economy program. Knowledge of the patient's pre-ward behavior was based on the perception of staff members who had known the patient previously. Needless to say this method is subject to serious bias.

Because the aides lacked grounding in token economy principles, they were overtly and covertly hostile toward the program. Several male aides who had been with the hospital for a number of years openly rejected the program. Both requested transfers, which were refused. They were refused because of the difficulty in obtaining other aides for the program due to problems inherent in the hospital system. One of the se aides was overheard telling a group of male patients that the program was a "lot of bull shit." The other male aide refused to rate 
patients and sabotaged the program in a number of ways. He subsequently terminated his employment with the hospital, when he could not obtain a transfer. Possibility of transfer was available, but it meant working the night shift, which was not considered desirable. Other aides, particularly female aides, expressed their hostility covertly. Although they complained bitterly among themselves, particularly during the early part of the program, about all of the extra work they were expected to do, they were frequently found sitting in the office engaged in conversation with each other. The staff psychiatrist pointed out to the aides that if the patients were able to care for their own needs it would actually mean more time for them. Eventually the aides recognized this possibility and became more cooperative.

Kazdin and Bootzin state that "training the staff to administer a token economy represents a formidable task for the effective use of reinforcement procedures." They also point out that attendants "often maintain inappropriate behavior by reinforcing deviant responses." This has also been a finding of Buehler, Furniss and Patterson (1966; Dobson, Gelfand and Gelfand, 1967); Ebner, unpublished. Kazdin and Bootzin note that contingencies are frequently arranged for the comfort and convenience of the attendants, rather than the treatment and training of the patients. This 
was also found in the studies of Dunham and Weinberg (1960);

Goffman (1961); Ullmann and Krasner (1969). The need for adequate staff training programs has been emphasized by many researchers;

e.g., Becker, Kuypers and O'Leary (1968); Krasner (1968); Miron, unpublished. The vital importance of adequate staff training has been noted by Ross (unpublished) who suggests that the staff remains "the Achilles' heel" of token economy programs. ${ }^{25}$

In a study of the personality structure of aides, Bernstein and Herzberg found that the aides were under pressure because of the lack of certainty regarding their roles, the lack of social status and a lack of intrinsic and extrinsic rewards in their jobs. As a result there was job dissatisfaction and a lack of communication with other staff members. ${ }^{26}$ This was observable in this program. Aides openly expressed and vented their feelings about the program among themselves. During staff meetings they were careful not to express the se feelings.

The Staff Psychiatrist did not have complete freedom to select the aide staff. They had to be selected within the framework of the hospital among the existing aides. The type of aide needed for programs that deviate from the customary custodial methods has been described by researchers. They are generally younger aides who have been with the hospital for a relatively short time. 
All of the aides on the token economy ward had been with the hospital for at least six years. Length of employment of the aides on the ward, all shifts, is as follows:

\begin{tabular}{|c|c|c|c|c|c|c|c|c|}
\hline 1 aide & . • • & - & • & - $\cdot$ & $\cdot$ & - & - & 19 years and 9 months \\
\hline 1 aide & . • & $\cdot$ & $\cdot$ & - $\cdot$ & '・ & - & - & 17 years and 6 months \\
\hline 3 aides & . . & & & • & . & . & - & $\begin{array}{l}16 \text { years and } 4 \text { months } \\
16 \text { years and } 7 \text { months } \\
16 \text { years and } 11 \text { months }\end{array}$ \\
\hline 2 aides & $\cdot$ & & & & - . & - & - & $\begin{array}{l}13 \text { years and } 3 \text { months } \\
13 \text { years and } 1 \text { month }\end{array}$ \\
\hline 1 aide & - $\cdot$ & - & & - & - $\cdot$ & $\cdot$ & $\cdot$ & 11 years and 3 months \\
\hline 1 aide & $\cdot \cdot \cdot$ & $\cdot$ & & $\cdot$ & - $\cdot$ & $\cdot$ & $\cdot$ & 8 years and 8 months \\
\hline 1 aide & . & & & • & • & • & $\bullet$ & 6 years \\
\hline
\end{tabular}

The swing shift nurse had been with the hospital for one year and six months. Although her status must be taken into consideration, it is interesting to note that she was very cooperative from the beginning of the program, and very much committed to the program.

One observed affect of long term service was that the aides generally knew or knew of the patient, prior to the patient's arrival on the token economy ward. Preconceived opinions of the patients were frequently voiced, particularly during the early part of the program. Aides made such statements as, "I know how to 
handle this, he has always behaved like this." Their handling of the patient was frequently counter to token economy principles. The following incidents were observed by this writer, which exemplify this problem:

a. A male patient, 16 years of age, who had spent a number of years in the hospital refused to bathe or wash his clothing. A female aide, employed by the hospital approximately 16 years, previously acquainted with the patient, continually scolded and nagged the patient for not washing his clothing. When the patient teased and ignored her threats, she quietly washed his clothing herself. The same aide refused to assist in the forced removal of an older female patient, who refused to leave her bed. She stated that the patient did not feel well. She had not asked for a medical examination.

b. A male aide, openly hostile to the program, did not collect fines for negative behavior. He spent a good deal of time talking with male patients, venting his feelings about the program. On one 
occasion he stated that one of the patients was like an old friend, as he had known him for many years. He acknowledged that he did not understand the program nor the principles of token economy therapy.

A young woman, angry because she was fined, began to yell and talk in a loud voice. She continued this behavior disrupting a ward meeting. This same aide sat with her, his arm around her shoulder, placating and soothing her for approximately 30 minutes. The standard procedure for this type of behavior is to immediately, without comment, seclude the patient until the proper behavior is emitted. 27

She received a good deal of reinforcement from the aide for her negative behavior.

Unfortunately, this negative type of reinforcement was not limited to the aides. Other staff members were seen on a number of occasions arguing, bargaining and placating patients. Dr. John Reid, Oregon Research Institute, made a courtesy study of the ward. He made the following observations on June 29th (1972). 
a. Work for which the patients were paid was not monitored or checked at the time of payment. This resulted in several hassles when the staff member later found that the patient had not actually completed the work for which she or he was paid (trying to get tokens back, lecturing patients, arguments, etc.).

b. One patient was not fined for taking off her clothes because "she was too sick to understand what was going on. "If this sort of reason is used to make many exceptions, you better forget the token economy.

c. Try to go out of your way to socialize with and support patients when they are acting normally, rather than when they are crying, acting bizarre, etc. 28

In regard to Dr. Reid's observations, these problems were fairly typical. In my opinion they were due in large part to lack of knowledge of token economy principles. The aides, conditioned to custodial duties, tended to interact with the patients the most when they were exhibiting negative behavior.

Inconsistency in fining patients was a constant problem. This 
could vary from staff member to staff member and from time to time with the same staff member. An example of this was the manner in which various staff members handled patients coming into the office area without permission. Some staff members merely threatened fines, but did not actually fine patients. Other staff members fined one time but not the next. Some fined certain patients consistently but not others. A number of times a group of younger patients were observed in the doorway putting one foot over the invisible line that separated the office from the hall. They would quickly withdraw their foot when the staff member threatened to fine them. A good deal of noisy interaction took place during this teasing. They were seldom fined.

One male aide, employed by the hospital for approximately 16 years, was very consistent in his behavior toward the patients. However, due to the day nurse's absence because of illness, he was put in charge of the shift. He received a good deal of verbal reinforcement from the Staff Psychiatrist as well as from other staff members.

Dr. Reid states in his June 29th letter, "The office routine was not going smoothly. Some patients burst into office, getting no fines, while others waited at door for permission to come in and got ignored. 129 
Behavior of the night shift was particularly interesting. As they did not come on duty until 10:30 p.m., they were not subject to observation, generally. The male and female aide for this shift were elderly. Both had been with the hospital for a number of years. Due to vacations, illness and days off they frequently worked the shift alone during the course of this study. During my observations they rarely recorded fines. The female aide tended to use a good deal of scolding and arguing, particularly when patients got up after the curfew demanding attention. The male aide generally ignored the patient's behavior. In fairness to the se aides, it should be noted that there is some danger involved in arousing the anger of psychotic patients, particularly when you are alone and there are anywhere from forty-four to fifty patients on the ward.

The following incidents occurred during observations of this shift:

a. Two male patients refused to go to bed, stating they could not sleep. They engaged in a lengthy conversation with the aide. It.was obvious that they were manipulating her to remain up. No fines were recorded.

b. An older female patient, not well liked because of 
her persistent demands for attention, came to the office after curfew stating she could not sleep. She was told to go to bed immediately or she would be fined. After a brief argument with the female aid, she left the area. She was later seen sitting in the hall. The aide again threatened her with a fine, demanding that she go to bed. She returned to the sleeping area. Although there were no fines involved for either the male patients or the female patient, there was good deal of difference in the behavior of the aide.

c. A young male patient came to the office at approximately $12: 30 \mathrm{a} . \mathrm{m}$. He did not immediately observe this writer who was working on files in a corner of the office not immediately visible from the door. He stated that everyone had gone and asked if he could now have his cigarette. Both he and aide appeared to be flustered, because I was in the office. Inasmuch as I was not a staff member, I told them to ignore me as 
I intended to leave shortly. He remained in

the office smoking until I left at approximately

la.m.

Ayllon and Azrin note in their study, "The way an attendant feels about a given patient will determine the likelihood of his rewarding the patient. $" 10$ As the aides had known the patients previously and had formed positive or negative opinions of the patients, this contributed to the inconsistency, insofar as their treatment of patients was concerned. There appear to be two problems to counteract when dealing with older, long term aides; lack of ability to adapt to new programs and previous preconceived opinions of the patient which affect their behavior toward the patient. Gripp and Magaro selected aides for their study after a number of interviews to determine the aides' ability to approach the treatment of chronic patients with optimism rather than the traditional custodial attitude and their willingness to apply a new method and philosophy of treatment. They found that the aides meeting these criteria were young and they had not worked in the hospital for a long period of time. ${ }^{31}$ Hansell and Benson also note that the aides best able to function in the token economy program were young and relatively inexperienced with the usual methods of handling chronic mental illness. ${ }^{32}$ Spiegel et al., in 
their study, 'Problems and Pitfalls of Establishing an Operant Conditioning-Token Economy Program," state that the staff must be lappropriate individuals who wish to be involved, who are enthusiastic about and who accept the philosophy of this type of treatment. " They also note that intensive training of all staff to be involved in the procedures of Operant-token economy is a necessity for all shifts. 33

Aside from staff problems, another serious problem on the ward was the lack of positive types of reinforcement available. As there were no funds to purchase commodities desired by the patients; the use of the tokens had to be limited to clothing which could be obtained from the hospital, T. V. on the ward, passes, meals, bed and recreational activities offered by the hospital. T. V., passes and recreational activity were free to patients on other wards. In contrast there were a number of behaviors the patient could be fined for.

After needed and wanted items were paid for, the patients who were high earners found that they were accumulating a surplus of tokens. One result was that patients began to pay in advance, or attempted to, for the privilege of engaging in negative behavior; e.g., swearing at staff members or other patients, shouting. Another group of patients, not motivated to earn surplus tokens, 
barely managed to pay for meals and bed. Others did not earn tokens and went into debt. Whether these low responders lacked motivation because of the few wanted items available, or lacked response for other reasons is not known. The researchers have pointed out that there are a group in every token economy who do not respond.

Ayllon and Azrin state that the emphasis should be placed on positive rewards rather than coercion or negative events. 34 I would agree with this, inasmuch as the purpose of the program is to institute positive behavior. Without sufficient positive reinforcers, it is also impossible to know why the low responders and non-responders behaved as they did.

Of course all of the above problems affected this study. Inasmuch as the Time-Series design required periodic ratings, it involved additional paper work for the raters. Some aides refused to rate patients, stating they were too busy. Others attempted to rate the patients, but were unable to complete the ratings until long after the rating period. These were discarded (three or four staff members rated during the early part of the study). Because of the necessity to discard ratings, only two raters were asked to rate during the balance of the study. Plans had been made to administer a rating sheet to the 
patients in order to obtain their perception of the ward. Ellsworth's "Patients Perception of Ward" test was used. This was used with permission of Ellsworth, as it is part of a larger study and not yet published. In this writer's opinion the patient perception rating sheet was too long and too complicated to be used with psychotic patients, however, the first rating sheet was received favorably by most patients.

The patients' perception of the ward was to be obtained at the beginning of the study period, midpoint in the study period and at the conclusion of the study period. The rating sheet was passed out to the patients during their regular ward meeting. Unfortunately, a few staff members viewed this study as an additional burden on the aides. When the midpoint rating was passed out, a staff member, particularly hostile to this study, dismissed the patients and the ratings were not completed. A decision was made to abandon this rating, rather than antagonize the staff. However, it is my belief that this information would have been of value to the staff.

Spiegel et al., in regard to the patient's perception of the treatment program states, Methods used to evaluate mental hospital treatment programs often neglect the voice of the group most deeply involved with program effects--the patients 
themselves." Spiegel et al., found that all but $8 \%$ of the patients in their study were able to make a definite decision regarding the most beneficial aspects of their treatment. 34

In summary, the program was plagued by a number of serious problems. The essential problems seemed to be the inability to select appropriate staff and lack of money. The latter was needed to institute training programs and to purchase sufficient desired commodities for token exchange to provide positive reinforcements for the program. 


\section{CHAPTER IV}

\section{FINDINGS}

A cohort of twenty-nine patients, eleven females and eighteen males took part in this study. The se patients came to the ward June Ist and remained on the ward until August 10th. Six of the se patients, two females and four males were among the fifty-one patients selected throughout the hospital to take part in a mountain climbing trip sponsored by the hospital. Fifty-one staff members throughout the hospital were also selected. The patients left the hospital on July 30th and returned August 15th. As the patients were not selected until this study was well underway, it was decided not to exclude these patients from the study. They were available for all of the testing periods, except the final evaluation. This was based, for the se patients, on their behavior prior to leaving the hospital.

The patients in this study are rated below the mean of Ellsworth's (1971) resident patients. The hypothesis of Mean = 55.2 is rejected with $p<.05$. We can therefore conclude that the present patients are rated significantly lower than Ellsworth's patients. 
TABLE I

SUMMARY STATISTICS FOR MACC RAW SCORES

OF SIX TESTING PERIODS USING TIME-SERIES DESIGN

\begin{tabular}{llllr}
\hline \hline Evaluation & Date and Rater & $\bar{X}$ & $S_{\mathbf{x}}$ \\
\hline I pre-test & $5 / 31$ & $1^{*}$ & 49.0 & 10.9 \\
& $5 / 31$ & 2 & 46.1 & 9.6 \\
token economy & & & & \\
initiated 6/1 & & & & \\
II test & $6 / 15$ & 1 & 45.3 & 8.6 \\
& $6 / 15$ & 2 & 52.3 & 11.4 \\
III test & $6 / 30$ & 1 & 52.8 & 9.7 \\
& $6 / 30$ & 2 & 52.0 & 11.3 \\
IV test & $7 / 15$ & 1 & 48.4 & 11.8 \\
& $7 / 15$ & 2 & 51.5 & 11.1 \\
V. test & $7 / 30$ & 1 & 51.2 & 10.9 \\
& $7 / 30$ & 2 & 51.2 & 10.6 \\
VI Final & $8 / 10$ & $1 * * *$ & 51.3 & 13.1 \\
Evaluation & & & &
\end{tabular}

$$
\bar{x} \vec{x}=50.1 \quad \overline{S D}_{x}=10.8 \quad n=29
$$

Ellsworth's Resident mean $=55.2$

(E11sworth, 1971

Ellsworth's Resident standard deviation $=12.4$

(Manual MACC

(Scale, table 7

* Raters 1 and 2 are not necessarily the same throughout the testing periods.

*** One rater used for final evaluation.

The patients in this study are rated below the mean of Ellsworth's (1971) resident patients. The hypothesis of Mean = 55.2 is rejected with $\mathrm{p}<.05$. We can therefore conclude that the present patients are rated significantly lower than Ellsworth's patients. 
TABLE II

AGREEMENT BETWEEN RATERS USING PEARSON'S r

\begin{tabular}{|c|c|c|c|c|c|c|c|c|c|c|c|}
\hline Date & Rater 1 & $5 / 31(2)$ & $6 / 15(3)$ & $6 / 15(4)$ & $6 / 30(5)$ & $6 / 30(6)$ & $7 / 15(7)$ & $7 / 15(8)$ & $7 / 30(9)$ & $7 / 30(10)$ & $8 / 10(11)$ \\
\hline $5 / 31$ & (1) & $.42^{*}$ & .14 & .24 & $.39^{*}$ & $.52^{* *}$ & .19 & .34 & $.47^{* *}$ & $.43^{*}$ & $.52^{* *}$ \\
\hline $5 / 31$ & (2) & & .04 & -.25 & -.01 & .08 & -.09 & -.10 & .05 & .03 & .35 \\
\hline $6 / 15$ & (3) & & & .33 & $.59^{* *}$ & .26 & $.43^{*}$ & $.52^{* *}$ & $.59^{* *}$ & $.67^{* *}$ & $43^{*}$ \\
\hline $6 / 15$ & (4) & & & & $.44^{*}$ & .34 & $.38^{*}$ & .35 & .33 & $.53^{* *}$ & .27 \\
\hline $6 / 30$ & (5) & & & & & .34 & .34 & $.38^{*}$ & $.56^{* *}$ & $.60^{* *}$ & $.56^{* *}$ \\
\hline $6 / 30$ & (6) & & & & & & .22 & .34 & $.43^{*}$ & $.47^{* *}$ & $.38^{*}$ \\
\hline $7 / 15$ & (7) & & & & & & & $.63^{* *}$ & $.42^{*}$ & $.47^{* *}$ & $.47^{* *}$ \\
\hline $7 / 15$ & (8) & & & & & & & & $.72^{* *}$ & $70^{* *}$ & $.57^{* *}$ \\
\hline $7 / 30$ & (9) & 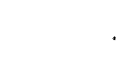 & & & & & & & & $.90^{* *}$ & $.63^{* *}$ \\
\hline $7 / 30$ & (10) & & & & & & & & & & $.66^{* *}$ \\
\hline
\end{tabular}

Ho: $\mathrm{P}=\mathrm{O}$

${ }^{*} \mathrm{P}(|\mathrm{r}| \geqslant .37)=.05$ indicated by $\mathrm{r} *$

$\mathrm{P}(|\mathrm{r}| \geqslant .47)=.01$ indicated by $\mathrm{r} * *$

$n=29, d f=27$ for Students' $t$.

$1_{\text {The raters are not necessarily the same pair throughout the testing periods. }}$ 
A comparison with Ellsworth's agreement between raters of $.75^{* * *}$ is significantly higher than the agreement found in this study. All except $r 7 / 30$ are less than .75 and $r 6 / 15$ and r $6 / 30$ are not significantly different from zero.

It should be noted that Ellsworth's figure is based on four raters differing shifts, table 4 . In this study two raters differing shifts were used and one rater for the final evaluation.

TABLE III

OBSERVED DATA FOR TEST OF ASSOCIATION BETWEEN SEX AND IMPROVEMENT $\mathrm{Chi}^{2}=2.4, \mathrm{P}>.10$

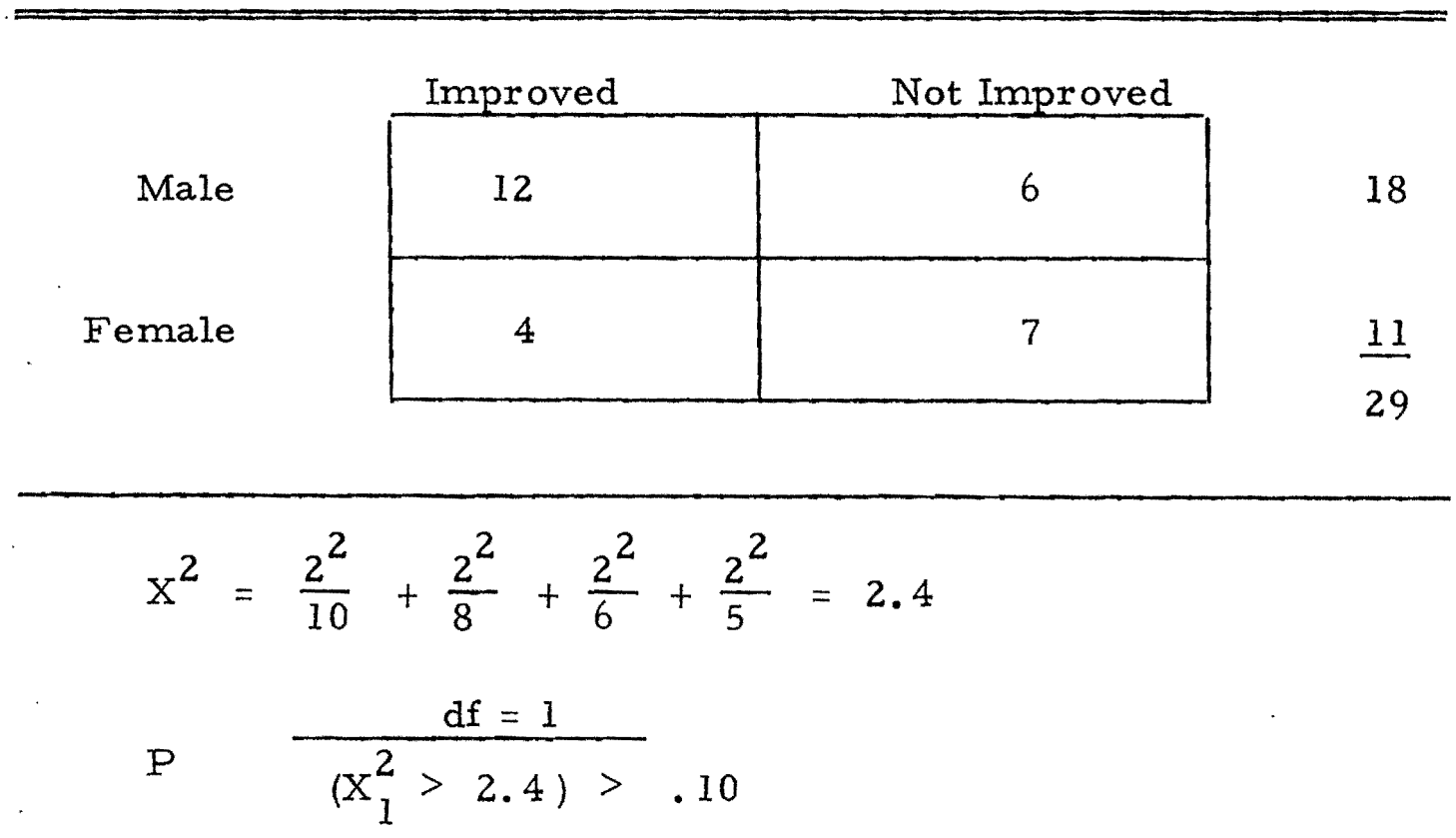


Initial scores were found for each patient by taking the mean of his old ward (pre-token economy) scores. The final score was used to measure improvement. (Final score - ward score mean) $>0$

Conclusion: The research hypothesis of association between the patient--sex and improvement was tested using Chi-square. Since $\mathrm{P}\left(\mathrm{Chi}_{1}^{2} \geqslant 2.4\right)>.10$, significant association between sex and improvement has not been demonstrated.

TABLE IV

ANOVA BETWEEN RATERS/EVALUATION DATES

\begin{tabular}{lcccc}
\hline Source & df & SS & MS & F \\
\hline Between Groups & 10 & 1931 & 193.1 & $1.634^{1}$ \\
Within Groups & 312 & 36883 & 118.2 & \\
\hline
\end{tabular}

SS $=$ Sum of squares

MS $=$ Mean square $=S S / D F$

$\mathrm{F}=\mathrm{MS}$ between $/ \mathrm{MS}$ within

$P(F \geqslant 1.634)>P(F \geqslant 1.86)=.05$ 
Of major interest in this study was the effect of being on the token economy ward. As different raters were used, a one way analysis of variance (ANOVA) was performed. Each evaluation was treated as a "group." $\mathrm{F}$ obs. $=1.63$. This is non-significant when compared with $\mathrm{F} .05,10,312=1.86$. It can thus reasonably be concluded that different raters do not introduce major effects in the data. A possible alternative conclusion might be that time (or treatment) does not introduce significant effects in this data. Another conclusion might be that treatment effects do exist but they are masked by rater effects. The low correlations support this possibility. However, it should be noted, that using the same raters throughout might introduce significant artifacts. "Blind" raters are ruled out insofar as the MACC Scale is concerned, as a knowledge of the patient is a prerequisite for rating the patient. For proper assessment of treatment a more objective test might possibly prove more satisfactory.

Given the relatively low r's found compared with Ellsworth's published $\mathrm{r}^{\prime} \mathrm{s}$, it appeared of some interest to determine whether, over time, the patients were distinguishable from each other. For technical reasons (the nature of the available "canned" statistical computer programs) only the first twenty of the twenty-nine patients were used. 
TABLE V

ANOVA BETWEEN PATIENTS

\begin{tabular}{|c|c|c|c|c|}
\hline Source & $\mathrm{df}$ & SS & MS & $F$ \\
\hline Between Groups & 19 & 10466 & 551 & $6.36^{*}$ \\
\hline Within Groups & 200 & 17315 & 86.6 & \\
\hline Total & 219 & 27781 & & \\
\hline
\end{tabular}

A one-way analysis of variance was run treating each patient as a "group." The Mean SD for each patient was found to be 9.1.* Thus there was considerable variability for each patient. The observed $F$ is significantly and certainly $P<.01$. Thus we can conclude that by combining data from several raters, we can reasonably expect to distinguish patients from each other.

Conclusions regarding the MACC behavioral Adjustment Scale Findings :

* This is comparable to the SD obtained by a single rater who is rating a large number of patients. 
1. The correlation matrix suggests that the reliability of evaluation in this test is not as high as Ellsworth suggest; $(r=$ 75 in table 4) specifically $\times 1,2$ are low as are $\times 3,4,5,6$; although $r 4,7,8,9,10$ tend to be high. In conclusion it could be stated that no significant effects for treatment were found utilizing Ellsworth MACC Behavioral Adjustment Scale. Raters 9, 10 and 11 had a higher correlation than earlier raters, thus it is possible earlier raters did not know the patient well enough to evaluate them properly. If this were true, it may account for the lack of significant effects of treatment.

2. Whatever improvement may have occurred, it was not associated with sex of patient.

3. Given the high $F$ found in the ANOVA between patients, the MACC Scale does distinguish between patients.

4. The Mean for all patients $(\overline{\mathrm{X}} \overline{\mathrm{X}})$ was significantly below the published Mean for Ellsworth's resident patients.

General findings in regard to the study were as follows:

1. The research design was weak as there were a number of extraneous variables affecting internal and external validity, which were not controlled.

2. The initial selection of patients was biased, as they were not selected according to research principles. 
Patients selected for the ward during the program were also subject to bias. The patient's current ward made the decision as to whether or not the patient should be transferred to the token economy program. This decision was sometimes based on a patient exchange. As none of the wards desired large numbers of difficult to manage patients, this selection was subject to bias.

3. A control group was not used nor was the token economy ward compared with any other ward in the hospital. Although this has also been true of a number of token economy studies, it does reflect the need for research which adheres to established research principles.

4. The staff was unable to properly operate the token economy program, as they not only lacked training but they lacked knowledge of token economy principles.

5. The staff lacked adequate reinforcement, particularly during the early part of the program. Thus the program was viewed as additional work for which there was no compensation.

6. The token economy program was heavily weighted toward deprivation for negative behavior rather than for rewards for positive behavior. 
7. Lack of funds prohibited the purchasing of needed items for the program. The result was "low purchasing power" for the token.

8. The length of time allotted for this study was insufficient. 
CHAPTER V

\section{EVALUATION}

The token economy program, according to the findings in this study, did not result in behavioral improvement of the patients during the course of this study. However, the study cannot be properly described as a test of a true token economy program. The program was not a true token economy, but a fusion of custodial treatment methods and token economy methods. The study could be described as "an exercise in futility. "It did result, however, in information which may be of use to other researchers and to individuals setting up token economy programs.

1. A true token economy program cannot be put into effect without extensive preliminary planning between all staff members, including aides in the program.

2. The hospital administration must give more than lip service" to the program. Funding is urgently needed, if the program is to be effective.

3. Patient selection must be unbiased, therefore randomization or some other accepted research method 
of selection must be utilized when selecting patients for the token economy program.

4. The entire staff needs to comprehend the value of research, if the program is to be continually evaluated as to its effectiveness. Research is also needed to determine which patients can benefit from the program and which patients cannot. Cooperative collaboration and planning needs to take place between the entire staff and the researchers.

5. More sophisticated statistical procedures are indicated. Due to problems inherent in the hospital setting, it is not always feasible to use randomization in patient selection or to use control groups. It is therefore necessary to go beyond simple statistical measures; e.g., one way analysis of variance.

6. Staff training involving the methods and principles of token economy therapy needs to be an integral part of the program, if the staff is to be an effective agent in the program.

In summary, the study did little but find there was no effect from treatment in a ward with mixed treatment methods. It did succeed in isolating serious problem areas, which need to be considered if a true token economy program is to operate in the State hospital. 


\section{CHAPTER VI}

\section{CONCLUSION}

From my research effort the conclusion has been reached that there is a direct relationship between the findings of "no improvement" in patients on the token economy ward during the first seventy days of the program and major problems inherent in the program, which interfered with effective functioning of the program.

The most crucial problem, in this writer's opinion, was the lack of a staff training program. The subsequent consequence was a lack of knowledge in regard to token economy loperant conditioning) principles. The resultant behavior of the staff was such as to frequently reinforce deviant patient responses. The need for staff training programs in token economy therapy has been documented by a large number of researchers. The staff, as Ross has pointed out, remain the "Achilles' heel" of token economy programs. 35

Central to all of the problems encountered was the lack of funds for this program. Setting up the program without funds was 
a Herculean feat, which deserves recognition. However, if the program is to develop into a viable, effective mode of therapy; funding will be necessary. Not only must staff training be an integral part of the program, but a continuous type of research needs to be included, if the effectiveness of the program is to be determined.

Research is also needed to resolve problems plaguing all researchers involved in token economies; e.g., does generalization of treatment effects take place in non-reinforced stimulus conditions; what specific type of patient benefits from token economy therapy; how, can high responders, operating above the level of the token economy, low responders and non-responder $s$ be discriminated; can more complex behaviors such as language and social behavior be brought under the control of token economy programs; how effective is token economy therapy in comparison to other modes of treatment; how does pre and post-treatment behavior of treated and untreated patients compare. These are some of the questions that need to be answered, if token economy therapy is to be effective.

Certainly, funding is a major problem, particularly in state mental hospitals, but as drug therapy empties the wards the spot light is focused on the residue, the chronic, institutionalized 
patients. Token economy therapy has been shown to be effective with this group. Although the State hospital does operate on a limited budget, funds must be found to help these "hard core" patients. The cost of permanently maintaining this group of patients in an institutional setting needs to be measured against the financial gain to the community, if these patients could be sent back to the community to live and in some cases to work. But even more important than the financial loss, which results from "warehousing" the se patients indefinitely, is the enormous cost in human waste. 
FOOTNOTES

$1_{\text {Teodoro Ayllon and Nathan Azrin, The Token Economy, a }}$ Motivational System for Therapy and Rehabilitation (New York: Appleton-Century-Crofts, Educational Division, Meredith Corporation, 1968), 2-3.

${ }^{2}$ Charles A. Stenger and Cecil P. Peck, "Token-Economy Programs in the Veterans Administration, "Hospital and Community Psychiatry, XXI (November, 1970), 371.

3

Ayllon and Azrin, op. cit. , p. 5.

4 Daniel G. Brown, "Behavior Modification with Children," Mental Hygiene, LVI (Winter, 1972), 22-30.

5

${ }^{5}$ Ayllon and Azrin, op. cit., p. 16.

6

Stenger and Peck, op. cit., p. 371.

${ }^{7}$ Gary M. Smith, "Experiencing Dehumanization in the Role of a Patient, "Mental Hygiene, LVI (Winter, 1972), 86.

${ }^{8}$ N. Hansel and M. L. Benson, IInterrupting Long Term Patienthood: A Cohort Study, "Archives of General Psychiatry, XXIV (January-June, 1971), 238.

${ }^{9}$ M. Karmel, "The Internalization of Social Roles in Institutionalized Chronic Mental Patients, "Journal of Health and Social Behavior, XI (September, 1970), 231-235.

${ }^{10}$ Hansell and Benson, op. cit., p. 338.

${ }^{11}$ Halmuth H. Schaefer and Patrick L. Martin, Behavioral Therapy (New York: McGraw-Hill, 1969), p. 8.

12 Brown, op. cit., p. 24. 
${ }^{13}$ Alan E. Kazdin and Richard R. Bootzin, "The Token Economy: An Evaluative Review, "Journal of Applied Behavior Analysis, V (Fall, 1972), 348.

14 Ibid. , p. 349.

15

Donna J. Allen and Peter A. Magaro, "Measures of

Change in Token-Economy Programs, "Behaviour Research and Therapy, IX (November, 1971), 311.

${ }^{16}$ Robert F. Gripp and Peter A. Magaro, "A Token Economy Program Evaluation with Untreated Control Ward Comparisons," Behaviour Research and Therapy, IX (November, 1971), 137.

${ }^{17}$ Allen and Magaro, op. cit. , p. 316.

18

Ibid., p. 317 .

${ }^{19}$ Ayllon and Azrin, op. cit. , p. 49.

${ }^{20}$ Kazdin and Bootzin, op. cit., p. 361.

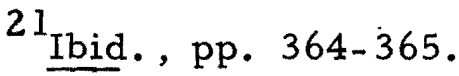

22 Donald T. Campbell, "Quasi-Experimental Designs for Use in Natural Social Settings" (Unpublished preliminary Draft prepared for Northwestern Univer sity-Carnegie Cor poration Project in Psychology-Education. First part of Paper published 1957), p. 10.

23 Robert B. Ellsworth, "The MACC Behavioral Adjustment Scale: Revised 1971 Manual, "published by Western Psychological Services, 12031 Wilshire Boulevard, Los Angeles, California, 90025 , p. 4; J. Rappaport and J. M. Chinsky, "Behavior Ratings of Chronic Hospitalized Patients: Cross-Situational and CrossRater Agreement, "Journal of Consulting and Clinical Psychology, XXXIV (June, 1970), 394-397.

$$
\begin{aligned}
& 24 \text { Ibid., p. } 3 . \\
& 25 \text { Kazdin and Bootzin, op. cit., p. } 345 .
\end{aligned}
$$


${ }^{26}$ Stephen Bernstein and Joseph Herzberg, "Small Group Experience with Psychiatric Aides, "Mental Hygiene, LIV (January, 1970), 113, 114.

27 Schaefer and Martin, op. cit., pp. 129-131.

28 John Reid (Oregon Research Institute), Letter to Dr. Gregory and Staff dated July 7, 1972.

${ }^{29}$ Ibid.

${ }^{30}$ Ayllon and Azrin, op. cit. , p. 11.

${ }^{31}$ Gripp and Magaro, op. cit., p. 140.

${ }^{32}$ Hansel and Benson, op. cit., p. 238.

${ }^{33}$ Jacqueline Montgomery and Raymond D. Mc Burney, 'Problems and Pitfalls of Establishing an Operant Conditioning-Token Economy Program, "Mental Hygiene, LIV (July, 1970), 383.

${ }^{34}$ Patricia Keith-Spiegel and Harry M. Grayson, "Using the Discharge Interview to Evaluate a Psychiatric Hospital, " Mental Hygiene, LIV (April, 1970), 298-300.

${ }^{35}$ Kazdin and Bootzin, op. cit., p. 345. 


\section{A SELECTED BIBLIOGRAPHY}

Atthowe, John M., and Leonard L. Krasner, "Preliminary report on the application of contingent reinforcement procedures (token economy) on a "chronic" psychiatric ward, "Journal of Abnormal Psychology, LXXIII (February, 1968), 37-43.

Ayllon, Teodoro, and Nathan Azrin, The Token-Economy, New York, Appleton-Century-Crofts, 1968.

Bandura, A., Principles of Behavior Modification, New York, Rinehart and Winston, 1969.

Boren, J. J., and A. D. Coleman, "Some Experiments on Reinforcement Principles Within a Psychiatric Ward for Delinquent Soldiers, "Journal of Applied Behavior Analysis, III (Spring, 1970), 29-37.

Buehler, R. E., G. R. Patterson, and J. M. Furniss, "The Reinforcement of Behaviour in Institutional Settings," Behaviour Research and Therapy, IV (August, 1966), 157 167.

Cotter, Lloyd H., "Operant Conditioning in a Vietnamese Mental Hospital, "American Journal of Psychiatry, CXXIV (July, 1967), 23-28.

Ellsworth, Joan R., 'Reinforcement Therapy with Chronic Patients, "Hospital and Community Psychiatry, XX (August, 1969), $36-38$.

Eysenck, H. J., 'New Ways in Psychotherapy, "Psychology Today, I (June, 1967), 39-47.

Gelfand, D. M., S. Gelfand, and W. R. Dobson, "Unprogrammed Reinforcement of Patients' Behaviour in a Mental Hospital, " Behaviour Research and Therapy, V (August, 1967), 201-207. 
Goffman, Erving, Asylums, New York, Doubleday, 1961.

Hartlage, Lawrence C., 'Subprofessional Therapists' Use of Reinforcement Versus Traditional Psychotherapeutic Techniques with Schizophrenics, " Journal of Consulting and Clinical Psychology, XXXIV (April, 1970), 181-183.

Hirschowitz, Ralph G., "Changing Human Behavior in the State Hospital Organization," The Psychiatric Quarterly, XXXXIII (October, 1969), 591-611.

Kale, R. J., J. H. Kaye, P. A. Whelan, and B. L. Hopkins, "The Effects of Reinforcement on the Modification, Maintenance and Generalization of Social Responses of Mental Patients, " Journal of Applied Behavior Analysis, I (Winter, 1968), 307-314.

Keller, F. S., Learning: Reinforcement Theory, New York, Random House, 1954.

Kennedy, Trudy, "Treatment of Chronic Schizophrenia by Behaviour Therapy: Case Reports, "Behaviour Research and Therapy, II (May, 1964), 1-6.

Lloyd, Kenneth E., and Leonard Abel, 'Performance on a Token Economy Psychiatric Ward: A Two Year Summary," Behaviour Research and Therapy, VIII (February, 1970), $1-9$.

Nurnberger, J. I., C. B. Ferster, and J. P. Brady, An Introduction to the Science of Behavior, New York, Appleton-Century-Crofts, 1963.

Panyan, M. , H. Boozer, and N. Morris, "Feedback to Attendants As a Reinforcer for Applying Operant Techniques, !" Journal of Applied Analysis, III (Spring, 1970), 1-4.

Rachman, S., "The Current Status of Behavior Therapy," Archives of General Psychiatry, XIII (November, 1965), $418-423$. 
Schaefer, H. H., and P. L. Martin, "Behavioral Therapy for 'Apathy' of Hospitalized Schizophrenics," Psychological Report, XIX (December, 1966), 1147-1158.

Schaefer, H. H., and P. L. Martin, Behavioral Therapy, New York, McGraw-Hill, 1969.

Sidman, M., Tactics of Scientific Research, New York, Basic Books, 1960 .

Steffy, R. A., Joan Hart, Margaret Crane, D. Torney, and Nancy Marlett, "Operant Behavior Modification Techniques Applied to a Ward of Severely Regressed and Aggressive Patients, "Canadian Psychiatric Association Journal, XIV (February, 1969), 59-67.

Ullmann, L. P., and L. Krasner, A Psychological Approach to Abnormal Behavior, New York, Prentice-Hall, 1969.

Vail, David J., Dehumanization and the Institutional Career, Springfield, Illinois, Charles C. Thomas, 1966.

Winkler, R. C., "Management of Chronic Psychiatric Patients by a Token Reinforcement System, "Journal of Applied. Behavior Analysis, III (Spring, 1970), 47-55. 
APPENDIX A

THE MACC BEHAVIORAL ADJUSTMENT

SCALE: REVISED 1971 (ELLSWORTH) 


\section{by}

Robert B. Ellsworth, Ph. D.

Published by

\begin{tabular}{l} 
DAP $2 \begin{array}{l}\text { WESTERN PSYCHOLOGICAL SERVICES } \\
\text { PUBLISHERS AND DISTRIBUTORS } \\
\text { 12031 WILSHIRE BOULEVARD } \\
\text { LOS ANGELES, CALIFORNIA 90025 }\end{array}$ \\
\hline A DIVISION OF MANSON WESTERN CORPORATION
\end{tabular}

\begin{tabular}{llll}
\hline Name: & & Sex: & M F \\
\hline Address or Ward: & & Activity Rated: & \\
\hline Rater's Name: & Rater's Position: & & Date Rated: \\
\hline Total Adjustment: $\quad$ Raw Score $=$ & Standard Score $=$ & & \\
\hline
\end{tabular}

\section{Directions for Rating:}

1. Rate only persons you know through personal observation or contact. 2. Be objective. Rate the person as you actually saw him behave and not as you wish or think he should behave. Do not let your personal feelings bias your rating. 3. Answer each of the sixteen questions by circling the number of the answer which most characteristically describes the behavior of the person being rated. 4. Do not give the same rating for all the questions; use your best judgment on each question. A person may be rated low on one question even though he may show a high level of adjustment on most other questions. 5. Rate quickly and do not hesitate to give extreme ratings if your observations point to such ratings. 6. Practice rating several persons, then discuss your ratings with one skilled in using this scale. Rate the same persons on two different occasions to improve the reliability of your ratings.

\section{Directions for Scoring:}

1. Write the number which has been circled as the answer for each of the sixteen questions in the box directly to its right. 2. To obtain the Mood, Cooperation, Communication, and Social Contact scores, add all the numbers in each of the appropriate columns and enter the total in the box at the bottom of that column. 3. The Total Adjustment score is the sum of the Mood, Cooperation, Communication, and Social Contact scores and is obtained by adding the numbers in the four boxes at the bottom of the columns and entering the sum in the Total Adjustment box to the right. 4. Transfer all scores to the profile by circling the score for each of the four scales and Total Adjustment.

PROFILE

\begin{tabular}{|c|c|c|c|c|c|c|c|c|}
\hline & $\begin{array}{l}\text { Standard } \\
\text { Score }\end{array}$ & Mood & Cooperation & Communication & $\begin{array}{l}\text { Social } \\
\text { Contact }\end{array}$ & $\begin{array}{c}\text { Total } \\
\text { Adjustment }\end{array}$ & $\begin{array}{l}\text { Standard } \\
\text { Score }\end{array}$ & \\
\hline \multirow{6}{*}{ ABOVE } & $\underline{70}$ & & \multirow[b]{3}{*}{20} & & \multirow[b]{3}{*}{20} & \multirow{3}{*}{$\begin{array}{l}79-80 \\
77-78\end{array}$} & 70 & \multirow{6}{*}{$=\frac{\text { ABOVE }_{4}}{\text { AVERAGE }}$} \\
\hline & 二 & & & & & & \multirow{2}{*}{$=$} & \\
\hline & $=$ & & & & & & & \\
\hline & 65 & -20 & 19 & $20=$ & 19 & $-75.76=$ & 65 & \\
\hline & $=$ & 19 & & & & 73.74 & - & \\
\hline & $\overline{60}$ & & 18 & 19 & 18 & 71-72 & 三 & \\
\hline \multirow{5}{*}{ AVERAGE } & $=$ & 18 & & 18 & 17 & $69-70^{\circ}$ & 60 & \multirow{5}{*}{ AVERAGE } \\
\hline & $\bar{z}$ & & 17 & 20 & & 67.68 & 二 & \\
\hline & $\overline{55}$ & 17 & $16^{\circ}$ & -17 & 16 & $\begin{array}{l}65.66 \\
63.64-.\end{array}$ & $\overline{55}$ & \\
\hline & 二 & & & 16 & 15 & 61.62 & 二 & \\
\hline & $\overline{50}$ & 16 & 15 & 10 & 14 & $59-60$ & 二 & \\
\hline \multirow{6}{*}{$\begin{array}{l}\text { BELOW } \\
\text { AVERAGE }\end{array}$} & 50 & 15 & & 15 & & 57.58 & 50 & \multirow{6}{*}{$\begin{array}{c}\text { BELOW } \\
\text { AVERAGE }\end{array}$} \\
\hline & 二 & & & & 13 & $55-56$ & 二 & \\
\hline & $\overline{45}$ & 14 & 13 & 14 & & $53-54$ & $\overline{75}$ & \\
\hline & $=$ & 13 & & 13 & & $\overline{51} \cdot \overline{52}$ & 45 & \\
\hline & 二 & & 12 & & 11 & $49-50$ & 二 & \\
\hline & $\overline{40}$ & -12 & & 12 & 10 & $47-48$ & $\overline{40}$ & \\
\hline \multirow{18}{*}{$\begin{array}{l}\text { VERY } \\
\text { LOW }\end{array}$} & 二 & & 11 & & & 45.46 & - & \multirow{5}{*}{$\begin{array}{l}\text { VERY } \\
\text { LOW }\end{array}$} \\
\hline & 二 & 11 & & 11 & 9 & $43-44$ & 二 & \\
\hline & $\overline{35}$ & -- & $-\ldots$ & 10 & -8 & $-41-42$ & -35 & \\
\hline & 二 & 10 & 9 & & & 39.40 & 二 & \\
\hline & 一 & & & 9 & 7 & $37-38$ & 二 & \\
\hline & $30-$ & $-9-$ & $-8-$ & & & $35-36$ & $-\overline{30}$ & - \\
\hline & 二 & & & 8 & 6 & 33-34 & 二 & \\
\hline & 二 & 8 & 7 & & & 31-32 & 二 & \\
\hline & $25-$ & $\overline{7}^{-}$ & $--\frac{-}{6}--$ & ---- & -- & $29-30-$ & -25 & \\
\hline & = & & & 6 & 4 & $27-28$ & 二 & \\
\hline & $\overline{20}$ & 6 & 5 & $5--$ & & $25 \cdot 26$ & $\overline{7}$ & \\
\hline & $=$ & & & $5--$ & -- & $\overline{20}-\overline{24}$ & 20 & \\
\hline & 二 & 5 & 4 & 4 & & & $=$ & \\
\hline & $15-$ & -- & ---- & ----- & --- & ---- & $\overline{15}$ & \\
\hline & 二 & 4 & & & & & 二 & \\
\hline & $\bar{E}$ & & & & & & 二 & \\
\hline & 10 & & & & & & 10 & \\
\hline & $\begin{array}{c}\mathrm{M} \\
\sigma\end{array}$ & $\begin{array}{r}15.25 \\
3.15\end{array}$ & $\begin{array}{r}14.50 \\
3.29\end{array}$ & $\begin{array}{r}15.15 \\
3.37\end{array}$ & $\begin{array}{r}13.77 \\
3.71\end{array}$ & $\begin{array}{l}58.29 \\
11.55\end{array}$ & $\begin{array}{c}\bar{M} \\
\sigma\end{array}$ & \\
\hline
\end{tabular}

Copyright (C) 1966, 1971 by WESTERN PSYCHOLOGICAL SERVICES 

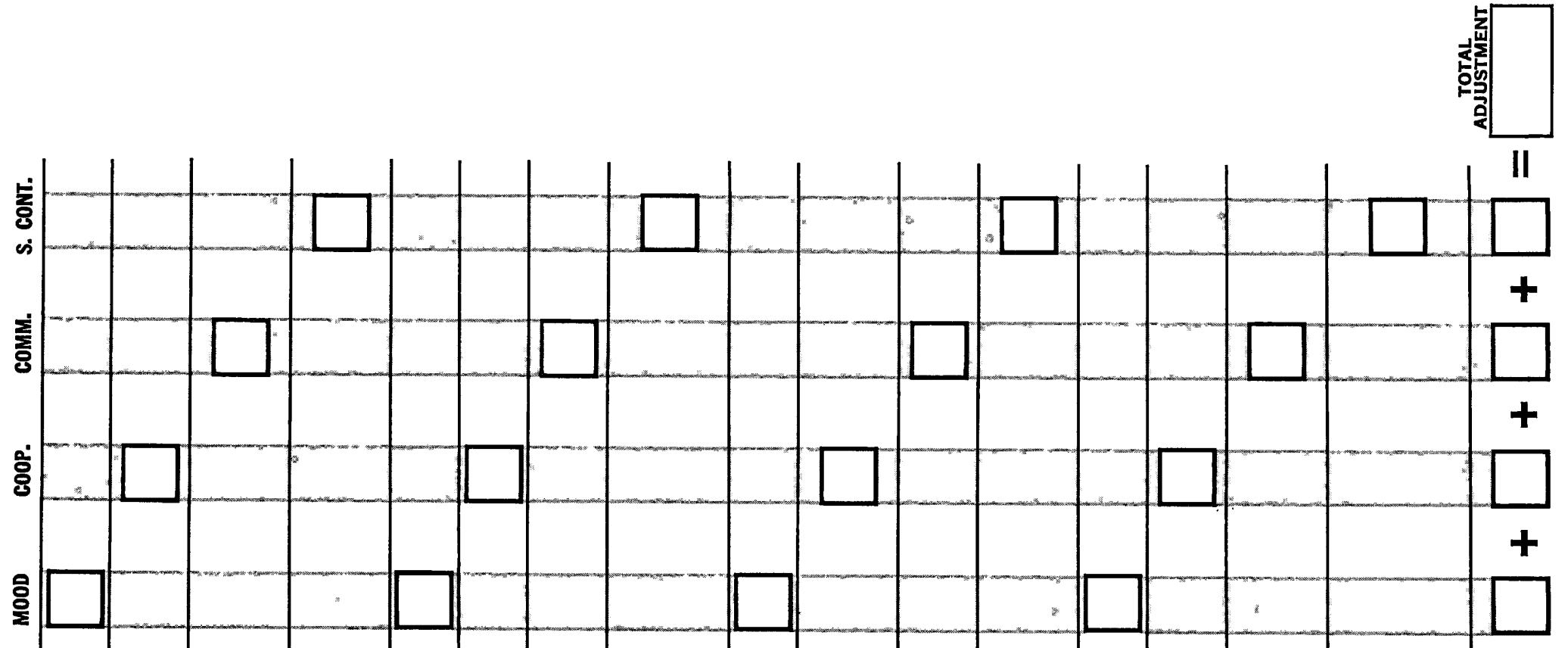
APPENDIX B

TOKEN ECONOMY MANUAL 
TOKEN ECONOMY WARD MANUAL

YOU have been chosen to be a member of the Token Economy Ward, because the staff feels that this program can be of benefit to you in helping you to return to your community.

The purpose of this program is to help you learn or relearn skills you need to know to function as an individual outside of the hospital setting.

You will have an opportunity to earn as much or as little as you like. Tokens will act as a substitute for money. You will have an opportunity to spend your tokens for privileges and luxuries, after your necessities are paid for. As you can see, the Token Economy works very much like the money economy outside of the hospital.

You will be given many opportunities to earn tokens. From your earnings you must first "purchase" your necessities, such as board and room. You may budget your tokens in any manner you choose. All of us value different things, therefore each person can use his extra tokens for the particular items that give him or her pleasure.

If you do NOT abide by the rules of the ward, which have been set up to make the ward a comfortable, pleasant place to stay, you will be fined. This is also true of the world outside of the 
hospital. We all have to obey certain rules, so that everyone can enjoy a maximum of privacy and safety.

As you have probably surmised by now, the ward is going to function very much like the community outside of the hospital. You will not be forced to work or behave as a responsible adult, but if you do not earn tokens you will suffer the same consequences as the individual who refuses to work in the community. You will not be able to pay for your bed, meals, privileges or luxuries.

This program, if you cooperate, can be your FIRST BIG STEP back to a life outside of the hospital. There may be bad days now and then; days you feel very unhappy about the ward, the staff and yourself. But isn't this true for all of us? None of us enjoy perfect days every day. Accepting the unpleasant with the pleasant is part of living too. The staff HAS FAITH IN YOU, or you would not have been chosen for this program. Now, HAVE FAITH IN YOURSELF!! YOU CAN MAKE IT!

\section{EMPLOYMENT PROCEDURE}

There will be job opportunities available for everyone who wants to work. The number of tokens paid for each job will vary, depending upon how difficult the job is.

Just as in the community outside of the hospital, your work 
record will depend upon whether or not you appear for work on time, properly dressed to go to work, and of course, how well you do your job. If you have a steady job you will receive a work card. Your work card will be presented to your work supervisor so that you will get full credit for the work you do.

Just as all of us must appear for work each working day, so must you. This means that you cannot pay or ask another person to work for you. If you do, you will be fined and you may lose other privileges.

Each person will have an opportunity to discuss the job to which he or she is assigned. If for some reason you would prefer another job, every effort will be made to help you find the "right job" for you. However, just as in the outside community, adjustments must be made; for various reasons we cannot always have the job we would like to have. You will have an opportunity to put your bid in for the job you would prefer. A good work record on the job you do have, will serve as a good reference when there is a job opening in the area you are interested in.

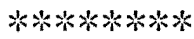

Below is a list of the various Industrial Therapy (I. T.) Assignments and their pay scale. The specific duties required for for each job will be explained on the job by the work supervisor. 
OFF WARD JOBS

\begin{tabular}{|c|c|c|c|}
\hline Engineers. & $\begin{array}{c}\text { Number of } \\
\text { Tokens }\end{array}$ & Other Jobs & $\begin{array}{l}\text { Number of } \\
\text { Tokens } \\
\end{array}$ \\
\hline $\begin{array}{l}\text { Greenhouse } \\
\text { male/female }\end{array}$ & $50 \mathrm{~T}$ per hour & $\begin{array}{l}\text { Linen Supply } \\
\text { male only }\end{array}$ & $75 \mathrm{~T}$ per hour \\
\hline $\begin{array}{l}\text { Ground Crews } \\
\text { male only }\end{array}$ & $75 \mathrm{~T}$ per hour & $\begin{array}{l}\text { Medical and } \\
\text { Surgical } \\
\text { male/female }\end{array}$ & $50 \mathrm{~T}$ per hour \\
\hline $\begin{array}{l}\text { Cement Crew } \\
\text { male only }\end{array}$ & $75 \mathrm{~T}$ per hour & $\begin{array}{l}\text { Geriatrics } \\
\text { male/female }\end{array}$ & $75 \mathrm{~T}$ per hour \\
\hline $\begin{array}{l}\text { Sanitary Crew } \\
\text { male only }\end{array}$ & $50 \mathrm{~T}$ per hour & $\begin{array}{l}\text { Library } \\
\text { male/female }\end{array}$ & $75 \mathrm{~T}$ per hour \\
\hline $\begin{array}{l}\text { Warehouse } \\
\text { male only }\end{array}$ & $50 \mathrm{~T}$ per hour & $\begin{array}{l}\text { Swimming Pool } \\
\text { male /female }\end{array}$ & $50 \mathrm{~T}$ per hour \\
\hline \multirow[t]{6}{*}{$\begin{array}{l}\text { Property Control } \\
\text { male only }\end{array}$} & $50 \mathrm{~T}$ per hour & $\begin{array}{l}\text { Clothing Room } \\
\text { female only }\end{array}$ & $75 \mathrm{~T}$ per hour \\
\hline & & $\begin{array}{l}\text { Mail Carts } \\
\text { male/female }\end{array}$ & $50 \mathrm{~T}$ per hour \\
\hline & & $\begin{array}{l}\text { Main Dining } \\
\text { Room } \\
\text { male/female }\end{array}$ & $\begin{array}{l}50-75 \mathrm{~T} \text { per } \\
\text { hour }\end{array}$ \\
\hline & & $\begin{array}{l}\text { East Dining } \\
\text { Room } \\
\text { male/female }\end{array}$ & $\begin{array}{l}50-75 \mathrm{~T} \text { per } \\
\text { hour }\end{array}$ \\
\hline & & $\begin{array}{l}\text { North Dining } \\
\text { Room } \\
\text { male/female }\end{array}$ & $\begin{array}{l}50-75 \mathrm{~T} \text { per } \\
\text { hour }\end{array}$ \\
\hline & & $\begin{array}{l}\text { Other Wards } \\
\text { male /female }\end{array}$ & $\begin{array}{l}50-75 \mathrm{~T} \text { per } \\
\text { hour }\end{array}$ \\
\hline
\end{tabular}


JOBS ON THE WARD

$\begin{array}{ll}\begin{array}{l}\text { Cleaning Women's Lavatory } \\ \text { female }\end{array} & 75 \mathrm{~T} \text { per hour } \\ \begin{array}{l}\text { Cleaning Men's Lavatory } \\ \text { male }\end{array} & 75 \mathrm{~T} \text { per hour } \\ \begin{array}{l}\text { Cleaning Day Room } \\ \text { male/female }\end{array} & 50 \mathrm{~T} \text { per hour } \\ \begin{array}{l}\text { Cleaning Hallways } \\ \text { male/female }\end{array} & 50 \mathrm{~T} \text { per hour } \\ \begin{array}{l}\text { Cleaning Library } \\ \text { male/female }\end{array} & 25 \mathrm{~T} \text { per hour } \\ \begin{array}{l}\text { Cleaning Music Room } \\ \text { male/female }\end{array} & 25 \mathrm{~T} \text { per hour } \\ \begin{array}{l}\text { Cleaning Women's Bed Area } \\ \text { female }\end{array} & 75 \mathrm{~T} \text { per hour } \\ \begin{array}{l}\text { Cleaning Men's Bed Area } \\ \text { male }\end{array} & 75 \mathrm{~T} \text { per hour }\end{array}$

$* * * * * * * * *$

SPECIAL WARD ASSIGNMENTS - WARD MONITORS

Monitors will be selected by the Staff. The assignments will change regularly. Every effort will be made to give everyone a chance to be a monitor.

\begin{tabular}{|c|c|c|c|}
\hline Monitor & Time & Tokens & Description \\
\hline $\begin{array}{l}\text { Wake-up } \\
\text { Monitor } \\
\text { one male / } \\
\text { one female }\end{array}$ & Up at $6: 20 \mathrm{a} . \mathrm{m}$. & $50 \mathrm{~T}$ a day & $\begin{array}{l}\text { At } 6: 30 \text { a.m. } \\
\text { wake each person, } \\
\text { check sheet when } \\
\text { person up. }\end{array}$ \\
\hline $\begin{array}{l}\text { Sleeping Area } \\
\text { Monitor } \\
\text { one male /one } \\
\text { female }\end{array}$ & $7: 20-7: 45$ a.m. & $50 \mathrm{~T}$ a day & $\begin{array}{l}\text { Check each } \\
\text { sleeping area } \\
\text { and note on check } \\
\text { sheet. }\end{array}$ \\
\hline
\end{tabular}




\begin{tabular}{|c|c|c|c|}
\hline Monitor & Time & Tokens & Description \\
\hline $\begin{array}{l}\text { Breakfast } \\
\text { Monitor }\end{array}$ & $7: 45-8: 10$ a.m. & $50 \mathrm{~T}$ a day & $\begin{array}{l}\text { Collect tokens } \\
\text { for breakfast. }\end{array}$ \\
\hline Lunch Monitor & $11: 45-12: 20$ p.m. & $50 \mathrm{~T}$ a day & $\begin{array}{l}\text { Collect tokens } \\
\text { for lunch. }\end{array}$ \\
\hline $\begin{array}{l}\text { Ward Meeting } \\
\text { Monitor }\end{array}$ & $2: 00-2: 15$ p.m. & $50 \mathrm{~T}$ a day & $\begin{array}{l}\text { Check off those } \\
\text { present and } \\
\text { not late. }\end{array}$ \\
\hline $\begin{array}{l}\text { Dinner } \\
\text { Monitor }\end{array}$ & 5:00-5:30 p.m. & $50 \mathrm{~T}$ a day & $\begin{array}{l}\text { Collect tokens } \\
\text { for dinner. }\end{array}$ \\
\hline T. V. Monitor & $5: 30-8: 15$ p. m. & $50 \mathrm{~T}$ a day & $\begin{array}{l}\text { Collect tokens, } \\
\text { change channels, } \\
\text { (after vote) keep } \\
\text { order. }\end{array}$ \\
\hline T.V. Monitor & $8: 15-10: 00$ p.m. & $50 \mathrm{~T}$ a day & $\begin{array}{l}\text { Regulate sound, } \\
\text { and same as } \\
\text { above. }\end{array}$ \\
\hline
\end{tabular}

The breakfast, lunch, dinner, ward and T.V. monitors may be either males or females.

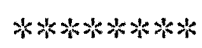

\section{GROUP MEETINGS}

Meetings will be held on the Ward as follows: Time: 2:153:15 p.m.

Every Monday and Wednesday

Every Thursday

Every Tuesday and Friday
General Ward Meeting with Staff present.

Small group Meeting for patients only.

Small group Meeting therapy meetings. 
Between 2:00-2:15 p.m. check in with the Attendance Monitor. Everyone attending meeting ON TIME will receive 50 tokens. If you are late, you will not receive any tokens.

If you do not attend a meeting you will be fined 75 tokens.

\section{GENERAL WARD MEETINGS}

General Ward Meetings are to discuss problems on the ward common to everyone. The meeting will be conducted by the Ward President and in (his or her) absence by the Vice President of the Ward.

Questions and issues may be raised at this meeting; all communication will take place at this meeting regarding problems on the ward that affect others.

\section{SMALL GROUP THERAPY MEETINGS}

You will be assigned to a small group, which will change in composition every four weeks. Small group therapy meetings will be used to do the following things:

1. Identify individual problems.

3. Overcome withdrawal tendencies.

5. Discuss problems to be faced outside of the hospital
2. Work on solving problems.

4. Provide feedback on each other.

6. Award tokens according to performance on Token Economy Program. (from 0 to 100 tokens.) 
GRIEVANCE COUNCIL

The Grievance Council consists of two ward members and two staff members. Meetings are held at 3:15 p.m. on Mondays and on any other day (same time) more than five grievances have accumulated. Emergency meetings may be called on special occasions at the request of a staff member. Grievances are to be put in writing (in sealed envelope) and given to a staff member at the same time you turn in your tokens. There will be a charge for presenting a grievance; if grievance valid it will be returned. Council members rotate.

SPECIAL ACTIVITIES

$\begin{array}{ll}\text { Woodshop } & \text { Tokens Received } \\ \text { Lapidary } & 50 \text { per hour } \\ \text { Swimming } & 50 \text { per hour } \\ \text { Gym } & 25 \text { per hour } \\ \text { Sewing classes } & 25 \text { per hour } \\ \text { O. T. } & 50 \text { per hour } \\ \end{array}$


SPECIAL ACTIVITIES- - Continued

\section{Tokens Paid}

Movies downtown

100

Movies on ward

25

Dances

50

Fishing

100

Pizza

100

Bowling

100

Skating

75

Trips

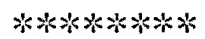

EXPECTED PERSONAL GROOMING FOR THE LADIES

(1) Bath daily, and use a deodorant. Be kind to others!

(2) Hair clean and neatly combed or brushed.

(3) Fingernails and toenails trimmed and clean.

(4) Teeth brushed.

(5) Face washed and make-up, if used, properly applied.

(6) Clothing, personal underthings as well as outer garments, clean, neat, and presentable to start your day. 


\section{EXPECTED PERSONAL GROOMING FOR THE MEN}

(1) Bath or shower daily and use a deodorant. Be kind to others!

(2) Hair clean and neatly combed.

(3) Shaved or neatly groomed, if wearing beards, mustaches, or sideburns.

(4) Face washed and teeth brushed.

(5) Fingernails and toenails clipped and clean.

(6) Outer and inner clothing clean and presentable, ready to start your day.

\section{YOUR NON-WORKING TIME}

Unless you are in seclusion or restricted because of dis ruptive behavior, and we hope you won't be, you will have freedom on the ward to purchase whatever type of leisure - time activity you wish. (T. V., movies, etc.)

If you wish to leave the ward and go on the hospital grounds, you may pay to do so. It is also necessary to have an Industrial Therapy (I.T.) assignment to be eligible for ground privileges. A \#2 card will be issued for this purpose.

Town passes (a day in town) will be issued to people purchas ing a \#3 card. As with ground privileges, the proper number of tokens must be paid and the purchaser must have an I. T. assignment. Written request must be turned in to a staff member before 
breakfast with the proper number of tokens.

Weekend Passes must be requested in writing and turned in on Wednesday afternoon before 2 p.m. with the proper number of tokens. Only people with I. T. assignments will be eligible for weekend passes.

\section{ADDITIONAL MEANS OF EARNING TOKENS}

On occasion, you will find it necessary or desirable to add to your daily earnings. There are many jobs that need to be done only occasionally. When you are ready to earn additional tokens, there are three places you can go: (1) to Jan, (2) to Joanne, and (3) to the ward staff. 


\section{DAILY SCHEDULE AND MEANS OF EARNING TOKENS}

\begin{tabular}{|c|c|c|}
\hline & Time & $\begin{array}{l}\text { Tokens } \\
\text { Received }\end{array}$ \\
\hline Wake up time & $6: 30$ p.m. & - \\
\hline Rising and dressing on time & $6: 30-7: 00$ a.m. & 75 \\
\hline Taking A. M. medications & $7: 00-7: 20$ a.m. & 25 \\
\hline Making beds and cleaning bed areas & $7: 20-7: 45$ a. $\mathrm{m}$ & 25 \\
\hline Going to breakfast & $7: 45-8: 10$ a.m. & - \\
\hline \multicolumn{3}{|l|}{ Goint to I. T. as signments } \\
\hline Noon medications & $11: 00-11: 20$ a.m. & 25 \\
\hline Going to lunch & $11: 45-12: 20$ p.m. & - \\
\hline \multicolumn{3}{|l|}{ Free Period for those not working } \\
\hline \multicolumn{3}{|l|}{ Afternoon check-in time } \\
\hline Monday - ward meeting & $2: 15-3: 15$ p.m. & 50 \\
\hline Tuesday - small group & $2: 15-3: 15$ p.m. & 50 \\
\hline Wednesday - ward meeting & 2:15-3:15 p.m. & 50 \\
\hline Thursday - ward meeting & $2: 15-3: 15$ p.m. & 50 \\
\hline Friday - small group & $2: 15-3: 15$ p.m. & 50 \\
\hline Afternoon medications & 4:00-4:20 p.m. & 25 \\
\hline Going to dinner & $5: 00-5: 35$ p.m. & - \\
\hline Evening medications & $8: 00-8: 20$ p.m. & 25 \\
\hline Bed time & $8: 00-10: 30$ p.m. & - \\
\hline Lights out & 10:30 p.m. & 50 \\
\hline
\end{tabular}


WARD PRICE LIST

Tokens Paid

Breakfast

2 meals a day must

Lunch

be purchased.

Dinner

Bed at night

100

Bed (other than at night or free time)

50 per hr.

\#2 card on grounds

25 per day or 100 per week

\#3 card off grounds

200 per day

Passes (weekend or week days)

150 per day

Visitors (other than on week-ends or free time)

25 per hr.

Private appointments

(Check with ward staff first)

Doctor

25 per $10 \mathrm{~min}$.

Social worker

25 per $10 \mathrm{~min}$.

Psychologist

25 per $10 \mathrm{~min}$.

Television (from 5:30-10:00 p.m. except Fri. and Sat.)

25 per evening

Television after lights out

50 per hr.

Staying up after lights out

50 per hr. 


\section{DISRUPTIVE BEHAVIOR}

When a disruptive behavior takes place, and a fine is necessary, the person will also go into a quiet room for 10 minutes. If the same fine is given more than once that week, 20 minutes in the quiet room, etc.

Tokens fined

Stealing (if caught more than once or twice, special tokens will be given to the stealers)

100

Fighting

100

Lending or borrowing of personal property

Creating a disturbance on ward

Disturbing others after lights out

Smoking in bed area

Unnecessary cursing

Watching T.V. unauthorized

Not attending scheduled meetings

Interrupting conversation or activities

Destruction of ward, hospital or private property

Lying or making a false report

For being on bed at wrong time 
Tokens fined

Not getting up on time $\quad 50$

second offense $\quad 75$

$\begin{array}{ll}\text { third offense } & 100\end{array}$

Failure to make bed and clean area $\quad 50$

Not sleeping in proper clothing $\quad 50$

Entering the aide's office uninvited 75

WELFARE BOARD

The purpose of the Welfare Board is to assist you in the event of emergency or if you have not earned sufficient tokens for a wanted privilege. These requests are to be in writing and given to a staff member when you turn your tokens in. Staff members may also call emergency Welfare Board Meetings, if they feel it is necessary.

If the Welfare Board decides that you have a valid request, they will loan you the requested number of tokens. If the request is not a valid one, you will be fined.

\section{WARD OFFICERS:}

Ward Officers will be elected by members of the ward. They will serve for a period of weeks. A President, Vice

President and Secretary will be elected. 米水冰冰水

THIS IS YOUR PERSONAL COPY OF THE TOKEN ECONOMY WARD MANUAL. DO NOT LOSE IT. YOU WILL NEED TO REFER TO IT "FOR TIMES AND JOBS AVAILABLE AS WELI AS COSTS OF VARIOUS ITEMS. THEY WILL NOT BE POSTED. 